\title{
Pengaruh Non-Probability Sampling Batubara terhadap Parameter Dry Ash Antara Certificate of Analysis Loading dan Unloading
}

\author{
Denny Murdany Muchsin \\ PT.PLN (Persero) \\ d3nny354@gmail.com; denny.murdany@pln.co.id
}

\begin{abstract}
Umpire test (referee test) may be conducted by the coal supplier based on the potential loss due to the difference Certificate of Analysis (COA) in both ports (loading and unloading). The purpose of the research was to determine a comparison of COA from non-probablity sampling complied to standard. The research method used quantitative methods by collecting COA data on both ports. These data on the receipt of coal was obtained from a coal-fired steam power plant (PLTU). A Sampling at both ports was conducted by the non-probability sampling method. The assumption was determined that the sample preparation and analysis process had complied with the American Standard Testing and Material (ASTM) standards. The ratio of ash (dry basis) in both COA to its average was processed statistically by taking confidence intervals with a confidence level of $95 \%$. This research showed that the ratio was in the range of $10.213 \%$ up to $16.793 \%$, exceeding precision $10 \%$ as required by ASTM D2234-16. Therefore, the comparison of COA data from non-probability sampling, could not be used as a reference for the doubt of the work of independent surveyors e.g. COA unloading, then it is technically that umpire test could not be conducted by such comparison.
\end{abstract}

Keywords: non-probability sampling, ash, coal, umpire

\begin{abstract}
ABSTRAK
Uji umpire (referee test) boleh dilakukan oleh pemasok batubara didasarkan pada potensi kerugian akibat perbedaan Certificate of Analysis (COA) di kedua port (loading dan unloading). Penelitian bertujuan untuk membuktikan ketidaktepatan perbandingan COA hasil non-probablity sampling di kedua pelabuhan. Metode penelitian menggunakan metode kuantitatif dengan mengumpulkan data COA di kedua port. Data penerimaan batubara diambil dari sebuah Pembangkit Listrik Tenaga Uap (PLTU). Pengambilan sampel baik di loading port (milik perusahaan pemasok) maupun unloading port (milik PLN) dilakukan dengan metode non-probability sampling. Asumsi telah ditetapkan bahwa proses preparasi dan analisa sampel telah sesuai dengan standar American Standard Testing and Material (ASTM). Rasio selisih ash (dry basis) pada kedua COA terhadap rata-ratanya diolah secara statistik dengan memperhitungkan confidence interval pada confidence level 95\%. Penelitian ini telah menunjukkan bahwa rasio tersebut berada pada rentang 10,213\% sampai dengan 16,793\%, melebihi presisi 1/10 (10\%) yang ditetapkan oleh ASTM D2234-16. Oleh karena itu, perbandingan data COA dari non-probability sampling, tidak dapat dijadikan acuan keraguan atas hasil kerja surveyor independen berupa COA di unloading port, sehingga secara teknis pengajuan umpire test oleh perusahaan pemasok tidak perlu dilakukan.
\end{abstract}

Kata kunci: non-probability sampling, ash, batubara, umpire 


\section{KILAT}

Vol. 9, No. 1, April 2020, P-ISSN 2089-1245, E-ISSN 2655-4925

DOI: https://doi.org/10.33322/kilat.v9i1.722

\section{PENDAHULUAN}

PLN sebagai salah satu badan usaha milik negara penyedia tenaga listrik bagi kepentingan umum memiliki misi menjalankan bisnis kelistrikan dari hulu (pembangkitan) hingga hilir (distribusi). Pada tahun 2018 PLN telah mengeluarkan biaya untuk bahan bakar dan pelumas (bagi pembangkit) sebesar Rp. 137,3 trilyun (44,5\% dari total beban usaha Rp. 308,2 trilyun), dimana biaya batubara sebesar Rp. 46,3 trilyun telah berkontribusi sebesar 58,3\% dari total produksi (188,7 TWh) Kontribusi batubara yang begitu besar harus menjadi perhatian utama dalam hal pengelolaan bahan bakar di unit-unit PLN yang memiliki PLTU batubara. [1].

Berdasarkan lokasi, PLTU batubara masih sangat didominasi oleh PLTU non Mulut Tambang yang sebagian besar menerima batubara melalui jetty dengan moda laut barge dan vessel. Pada kontrak jual beli batubara dengan skema CIF (Cost, Insurance, and Freight), titik penyerahan batubara berada di jetty PLN dimana kualitas diukur oleh surveyor independen dan dituangkan dalam Certificate of Analysis (COA) Unloading yang disepakati sebagai sebagai dasar perhitungan penyesuaian/penalti harga. Penyesuaian harga dapat beimplikasi menguntungkan atau pun merugikan bagi PLN. Adapun di titik pengiriman (loading port) pengukuran kualitas juga dilakukan oleh surveyor independen yang dituangkan dalam COA Loading sebagai dasar konfirmasi oleh PLN apakah batubara boleh dikirim atau tidak.

Ketika proses unloading batubara selesai dilakukan, pembayaran akan dilakukan dengan beberapa price adjustment yang merujuk pada COA Unloading. Ini lah yang menjadi salah satu titik krusial bagi kedua belah pihak bergantung kepentingan masing-masing pihak. Pada kontrak perjanjian jual beli batubara terdapat klausul: "Jika terjadi keragu-raguan dari salah satu pihak terhadap hasil analisa kualitas LRC oleh independent surveyor, maka pihak yang meragukan dapat meminta untuk dilakukan analisa kualitas LRC terhadap umpire sample dengan disaksikan oleh pihak lainnya". Proses pengujian ulang kualitas batubara terhadap umpire sample biasa disebut sebagai umpire test.

Acuan teknis mengenai "keragu-raguan" sebagai dasar umpire test tidak tertuang di dalam kontrak. Oleh karenanya, jika pemasok merasa dirugikan dengan price adjustment maka pemasok dapat mengajukan umpire test karena meragukan COA Unloading yang berbeda signifikan dengan COA Loading yang mana kedua-duanya melakukan pengambilan sampel yang bukan probability sampling. Umumnya, pengambilan sampel dilakukan secara manual di belt conveyor yang bergerak dan di stockpile. Hasil umpire test ketika umpire test diajukan, maka pemasok berpeluang diuntungkan.

Semakin homogen sebuah populasi maka semakin sederhana pengambilan sampel dan juga sebaliknya. Batubara memiliki heterogenitas yang tinggi sehingga dalam penentuan kualitas batubara diperlukan pengambilan sampel yang lebih kompleks dengan memenuhi salah satu prinsip dasar yaitu seluruh populasi batubara yang akan diambil sampel memiliki probabilitas yang sama. [2] 


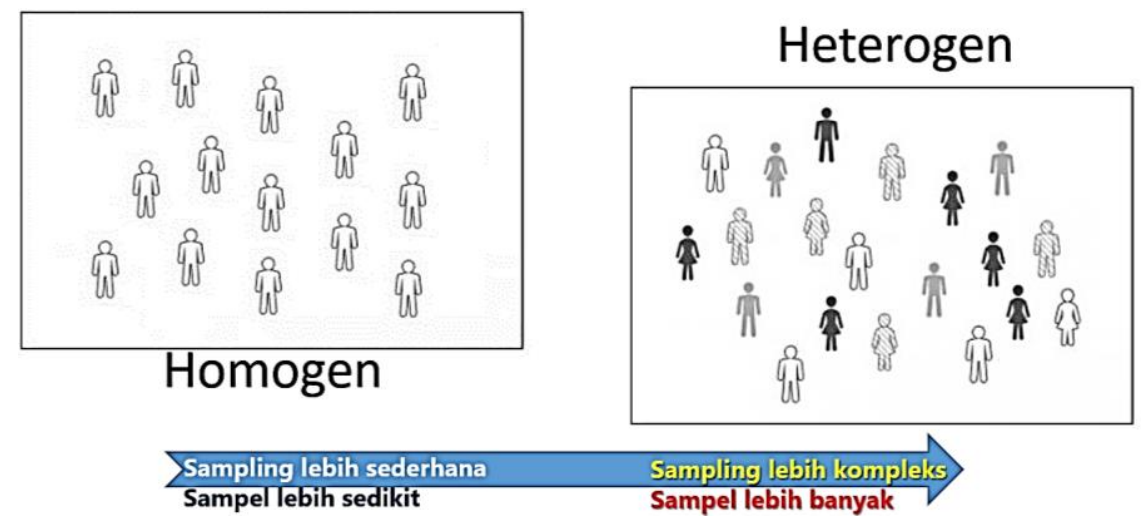

Gambar 1. Ilustrasi Kompleksitas Sampling terkait Heterogenitas Populasi

Adapun pengambilan sampel secara garis besar terbagi atas 2 (dua) yaitu probability sampling dan non-probability sampling. Probability sampling meniadakan kemungkinan pemilihan sampel sehingga setiap butiran batubara memiliki hak yang sama untuk dipilih sebagai sampel. Sampling jenis ini digunakan ketika keterwakilan seluruh populasi menjadi penting untuk suatu kepentingan yang lebih luas. Sebaliknya, non-probability sampling memunculkan kemungkinan pemilihan sampel sehingga tidak semua elemen di dalam populasi punya hak yang sama untuk dipilih sebagai sampel dan oleh karenanya sampling tersebut hanya mewakili sebagian elemen populasi saja. Sampling jenis ini cocok ketika terbatasnya waktu dan budget untuk sampling. [3]

Pengambilan sampel batubara berdasarkan ASTM D2234 terbagi atas 4 (empat) kondisi: A (full cross section cut di atas belt conveyor yang berhenti); B (full cross section cut di atas atau di jatuhan aliran belt conveyor yang bergerak); $\mathrm{C}$ (non-full section cut atau part stream cut di atas atau di jatuhan aliran belt conveyor yang bergerak); D (sebagian sampel yang diambil dari stockpile, tongkang, vessel, kereta, truk). Pengambilan sampel secara manual dilakukan pada kondisi A, C, dan D. Pengambilan sampel secara mekanikal dilakukan pada kondisi B dan D.

Yang termasuk probability sampling adalah kondisi A dan B. Namun, kondisi A tidak tepat digunakan untuk keperluan operasional rutin, sehingga kondisi B yang lebih tepat. Probability sampling jika dilakukan secara berulang terhadap populasi batubara yang sama, maka hasil analisa abu kering dari kedua pengambilan tersebut akan berada pada interval tidak lebih daripada 1/10 atau $10 \%$ dari rata-rata abu kering dengan tingkat kepercayaan 95\%. Oleh karenanya, jika di loading maupun unloading port menggunakan kondisi B, maka pengujian atau asesmen terhadap proses sampling di kedua port dapat dilakukan. [4]

Kondisi A digunakan untuk keperluan bias test yang dijadikan sebagai referensi bias terhadap kondisi B. Alat pengambilan sampel kondisi B harus dilakukan bias test ketika awal instalasi awal maupun saat ada perubahan teknis dari belt conveyor. [5]

Kondisi $\mathrm{C}$ dan $\mathrm{D}$ termasuk non-probablity sampling yang tidak memiliki presisi parameter dry ash seperti halnya kondisi A dan B. Kondisi C hanya boleh dilakukan jika kondisi B sedang tidak dapat dilakukan dikarenakan kerusakan atau pun lainnya. Sedangkan kondisi D dilakukan hanya untuk memperkirakan kualitas batubara dan tidak bisa representatif terhadap seluruh populasi batubaranya. [6]

Penelitian ini bertujuan untuk membuktikan ketidaktepatan perbandingan COA hasil nonprobablity sampling di kedua pelabuhan dengan pendekatan ketentuan presisi 1/10 sesuai ASTM D2234. Jika pembuktian berhasil dilakukan, maka upaya membandingkan COA loading dengan unloading dipastikan tidak tepat. Oleh karenanya, pembuktian ini akan mengarahkan klausul kontrak 


\section{KILAT}

Vol. 9, No. 1, April 2020, P-ISSN 2089-1245, E-ISSN 2655-4925

DOI: https://doi.org/10.33322/kilat.v9i1.722

tentang umpire test supaya dibuat lebih teknis dan rinci sehingga transaksi jual-beli batubara dapat memegang objektivitas yang benar sesuai standar. Selain itu, pembuktian ini bisa memperkuat keyakinan kedua belah pihak (supplier dan buyer) untuk menaikkan kondisi pengambilan sampel di loading port dan unloading port menjadi kondisi B. Sebagai info, pengurangan harga atau penalti batubara akibat kualitas batubara yang diterima (COA unloading) tidak sesuai dengan kontrak, tidak lah sebanding dengan kerugian pembangkit listrik yang alami baik dari sisi keandalan, gangguan, maupun efisiensi. Oleh karenanya, PLN selaku buyer pun punya kepentingan terhadap COA loading walaupun jenis kontrak CIF sehingga buyer punya peluang lebih baik dalam memastikan kualitas batubara yang akan dikirim oleh supplier.

\section{METODE PENELITIAN}

Proses penelitian ini meliputi pengambilan data sekunder, pengolahan data, dan analisa statistik. Penelitian ini dilakukan pada PLTU (Pembangkit Listrik Tenaga Uap) Teluk Balikpapan 2 x 110 MW yang berlokasi di Kota Balikpapan, Kalimantan Timur. PLTU berbahan bakar batubara jenis LRC (Low Rank Coal, kriteria royalti) ini disuplai batubaranya oleh 3 (tiga) pemasok dari dalam negeri dengan nilai tipikal Gross Caloric Value $4.000 \mathrm{kKal} / \mathrm{kg}$ (as received basis).

\subsection{Pengambilan Data Sekunder}

Data-data sekunder yang digunakan di dalam penelitian ini adalah moisture in the analysis sample (\% weight, as determined basis) dan ash (\% weight, as determined basis). Data tersebut diperoleh dari dokumen COA loading dan COA unloading pada setiap lot penerimaan yang diterbitkan oleh lembaga surveyor independen yang telah terakreditasi KAN (Komite Akreditasi Nasional). Data sekunder yang diambil berasal dari proses penerimaan batubara oleh PLTU Teluk Balikpapan pada tgl. 5 Januari 2019 hingga 21 Juli 2019 sebanyak 60 lot penerimaan.

Pengambilan sampel baik di loading port maupun unloading port dilakukan dengan jenis nonprobability sampling secara manual di stockpile (kondisi D menurut ASTM D2234) dan belt conveyor bergerak (kondisi C menurut ASTM D2234). Proses preparasi dan pengujian oleh surveyor independen dilakukan sesuai ASTM D2013 (preparasi), ASTM D3173 (moisture in the analysis sample), dan ASTM D3174 (ash). [7] [8] [9]

\subsection{Pengolahan Data}

Sepasang data ash (\% weight, as determined basis) yang berasal dari COA loading dan COA unloading dikonversi ke ash (\% weight, dry basis) menggunakan formula sesuai ASTM D3180: [10]

$a s h_{d b}=\frac{100}{100-m_{a d}} x a s h_{a d}$

yang $a s h_{d b}$ sebagai nilai ash (loading/unloading) dalam dry basis dengan satuan $\%, m_{a d}$ sebagai nilai moisture in the analysis sample dengan satuan $\%$, dan $a s h_{a d}$ sebagai nilai ash dalam as determined basis dengan satuan \%. Dari perhitungan tersebut maka akan didapatkan ash $_{d b}$ loading dan $a s h_{d b}$ unloading.

Kedua data $a s h_{d b}$ yang didapatkan dari formula di atas lalu dirata-ratakan dengan formula:

$\overline{a s h}_{d b}=\frac{a_{d b} \text { loading }+a s h_{d b} \text { unloading }}{2}$ 
yang $\overline{a s h}_{d b}$ sebagai rata-rata (mean) ash dalam dry basis. Setelah itu, absolut selisih $a s h_{d b}$ loading dengan $a s h_{d b}$ unloading $(\Delta)$ dihitung dengan formula:

$\Delta=\mid a_{d b}$ loading $-a_{s} h_{d b}$ unloading $\mid$.

Selanjutnya, persentase rasio $\Delta$ terhadap $\overline{a s h}_{d b}$ dihitung dengan formula:

rasio $=\frac{\Delta}{\overline{a s h}_{d b}} \times 100$.

Semua perhitungan tersebut dilakukan pada data tiap lot penerimaan batubara sehingga mendapatkan 60 data rasio yang akan diolah secara statistik untuk mendapatkan nilai rentang rasio pada tingkat kepercayaan $95 \%$.

\subsection{Analisa Statistik}

Pengolahan secara statistik menggunakan tools formula dari Microsoft Excel 2019 antara lain: "average" untuk menghitung $\bar{X}$ (satuan \%) atau rata-rata; "stdev" untuk menghitung $S_{X}$ (satuan \%) atau simpangan baku; dan "confidence. $t$ " untuk menghitung interval kepercayaan (satuan \%) terhadap rata-rata dengan distribusi $\mathrm{T}$ Student. Ketika interval kepercayaan telah dihitung, rentang rasio pada tingkat kepercayaan $95 \%(\alpha=0,05)$ dapat dihitung dengan formula rentang rasio $=$ $\bar{X} \pm$ interval kepercayaan.

Tabel 1. Data Masukan dan Keluaran Formula Excel

\begin{tabular}{|r|l|l|l|}
\hline No. & Formula Excel & \multicolumn{1}{|c|}{ Data Masukan } & Data Keluaran \\
\hline 1 & average & 60 data rasio hasil pengolahan data dari semua lot & $\begin{array}{c}\text { Rata-rata rasio } \\
\bar{X}\end{array}$ \\
\hline 2 & stdev & 60 data rasio hasil pengolahan data dari semua lot & $\begin{array}{c}\text { Simpangan baku rasio } \\
S_{X}\end{array}$ \\
\hline 3 & confidence.t & - alfa yaitu 1-confidence level $=0,05$ & Interval kepercayaan \\
& - simpangan baku rasio & \\
& - jumlah populasi $=60$ & \\
\hline
\end{tabular}

\section{HASIL DAN PEMBAHASAN}

Pengolahan data awal yaitu konversi ash (as determined basis) ke ash (dry basis) ditunjukkan oleh Tabel 2 dan dapat dilihat bahwa ash (dry basis) seluruhnya lebih besar daripada ash (as determined basis) karena peniadaan berat moisture. 
KILAT

Vol. 9, No. 1, April 2020, P-ISSN 2089-1245, E-ISSN 2655-4925

DOI: https://doi.org/10.33322/kilat.v9i1.722

Tabel 2. Hasil Konversi ash (ad) ke ash (db)

\begin{tabular}{|c|c|c|c|c|c|c|c|c|c|c|c|c|c|c|c|}
\hline \multirow[b]{2}{*}{ No. } & \multirow{2}{*}{$\begin{array}{c}\text { Tanggal } \\
\text { Penerimaan }\end{array}$} & \multicolumn{3}{|c|}{ COA Loading } & \multicolumn{3}{|c|}{ COA Unloading } & \multirow[b]{2}{*}{ No. } & \multirow{2}{*}{$\begin{array}{c}\text { Tanggal } \\
\text { Penerimaan }\end{array}$} & \multicolumn{3}{|c|}{ COA Loading } & \multicolumn{3}{|c|}{ COA Unloading } \\
\hline & & \begin{tabular}{|l|} 
MiAS \\
(ad), \%
\end{tabular} & \begin{tabular}{|c|} 
Ash \\
$(\mathrm{ad}), \%$
\end{tabular} & \begin{tabular}{|c|} 
Ash \\
(db), \% \\
\end{tabular} & \begin{tabular}{|c|} 
MiAS \\
$(\mathrm{ad}), \%$
\end{tabular} & \begin{tabular}{|c|} 
Ash \\
$(\mathrm{ad}), \%$ \\
\end{tabular} & \begin{tabular}{|c|} 
Ash \\
(db), \%
\end{tabular} & & & \begin{tabular}{|l|} 
MiAS \\
(ad), \%
\end{tabular} & \begin{tabular}{|c|} 
Ash \\
$(\mathrm{ad}), \%$
\end{tabular} & \begin{tabular}{|c|} 
Ash \\
$(\mathrm{db}), \%$
\end{tabular} & $\begin{array}{l}\text { MiAS } \\
\text { (ad), \% }\end{array}$ & \begin{tabular}{|c|} 
Ash \\
$(\mathrm{ad}), \%$
\end{tabular} & \begin{tabular}{|c|} 
Ash \\
(db), \% \\
\end{tabular} \\
\hline 1 & $05 / 01 / 2019$ & 14,60 & 5,40 & 6,32 & 22,30 & 4,90 & 6,31 & 31 & $24 / 04 / 2019$ & 17,20 & 4,60 & 5,56 & 21,60 & 4,90 & 6,25 \\
\hline 2 & $09 / 01 / 2019$ & 18,60 & 4,80 & 5, & 27,40 & 4,00 & 5,51 & 32 & $/ / 05 / 2019$ & 15,00 & 5,90 & 6,94 & 23,60 & 5,40 & 7,07 \\
\hline 3 & $16 / 01 / 2019$ & 12,60 & 5,20 & 5,95 & 24,50 & 5,00 & 6,62 & 33 & $06 / 05 / 2019$ & 18,30 & 4,60 & 5,63 & 25,60 & 4,60 & 6,18 \\
\hline 4 & $18 / 01 / 2019$ & 17,70 & 4,90 & 5,95 & 25,20 & 4,80 & 6,42 & 34 & & 13,50 & 4,70 & 5,43 & 24,40 & 4,50 & 5,95 \\
\hline 5 & $21 / 01 / 2019$ & 12,90 & 5,30 & 6,08 & 25,10 & 5,70 & 7,61 & 35 & $12 / 05 / 2019$ & 17,75 & 5,18 & 6,30 & 23,20 & 5,60 & 7,29 \\
\hline 6 & $24 / 01 / 2019$ & 14,00 & 7,50 & 8,72 & 25,20 & 5,90 & 7,89 & 36 & & 13,00 & 6,00 & 6,90 & 23,50 & 6,80 & 8,89 \\
\hline 7 & $30 / 01 / 2019$ & 13,80 & 7,00 & 8,12 & 23,20 & 9,20 & 11,98 & 37 & $5 / 2019$ & 17,40 & 4,50 & 5,45 & 25,00 & 4,40 & 5,87 \\
\hline 8 & $01 / c$ & 17,70 & 5,20 & & 23,30 & 5,30 & 6,91 & 38 & & 18,20 & 50 &, 50 & 21,20 & 60 & 5,84 \\
\hline 9 & $03 / 02 / 2019$ & 19,40 & 6,10 & 7,57 & 22,10 & 8,30 & 10,65 & 39 & $5 / 2019$ & 19,36 & 4,28 & 5,31 & 25,70 & 5,30 & 7,13 \\
\hline 10 & $11 / 02 / 2019$ & 14,30 & 6,30 & 7,35 & 20,30 & 7,80 & 9,79 & 40 & & 14,10 & 20 & 22 & 24,80 & 80 & 9,04 \\
\hline 11 & $11 / 02 / 2019$ & 17,98 & 5,01 & 6,11 & 20,00 & 5,70 & 7,13 & 41 & & 16,10 & 6,00 & 7,15 & 23,00 & 5,30 & 6,88 \\
\hline 12 & $18 / 0$ & 17,40 & 5,50 & & 16,90 & 0 & 6,62 & 42 & & 18,50 & 80 & 89 & 5,80 & 40 & 5,93 \\
\hline 13 & $22 / 0$ & 15,50 & 5,90 & 6,98 & 16,62 & 6,12 & 7,34 & 43 & & 16,30 & 5,20 & 6,21 & 26,50 & 6,30 & 8,57 \\
\hline 14 & $02 / 4$ & 13,10 & 5,30 & 6,10 & 26,20 & 4,6 & 6,2 & 44 & & 15,00 & 5,40 & 6,35 & 26,50 & 5,30 & 7,21 \\
\hline 15 & $04 / 03 / 2019$ & 17,38 & 6,98 & 8,45 & 23,90 & 4,70 & 6,18 & 45 & $10 /$ & 18,30 & 4,90 & 6,00 & 24,20 & 4,50 & 5,94 \\
\hline 16 & $09 / 4$ & 16,55 & 5,09 & & 21,40 & 6,9 & 8, & 46 & & 18,60 & 5,00 & 6,14 & 25,00 & 4,30 & 5,73 \\
\hline 17 & $11 / 03 / 2019$ & 16,40 & 4,90 & 5,86 & 25,00 & 4,60 & 6,13 & 47 & $16 /$ & 13,70 & 6,40 & 7,42 & 24,20 & 6,10 & 8,05 \\
\hline 18 & $17 / 0$ & 13,10 & 5,30 & & 17,60 & 90 & 7, & 48 & & 17,20 & 4,40 & 5,31 & 22,90 & 4,40 & 5,71 \\
\hline 19 & $21 / 03 / 2019$ & 14,60 & 5,70 & 6,67 & 16,40 & 6,70 & 8,01 & 49 & $6 / 2019$ & 17,92 & 5,58 & 6,80 & 24,10 & 4,60 & 6,06 \\
\hline 20 & $23 / 03 / 2019$ & 16,80 & 4,50 & 5,41 & 23,60 & 4,40 & 5,76 & 50 & & 18,40 & 4,50 & 5,51 & 21,30 & 4,50 & 5,72 \\
\hline 21 & $26 / 03 / 2019$ & 13,90 & 6,50 & 7,55 & 25,00 & 6,80 & 9,07 & 51 & $26 / 06 / 2019$ & 18,10 & 5,10 & 6,23 & 23,20 & 4,40 & 5,73 \\
\hline 22 & $29 / 03 / 2019$ & 17,80 & 4,90 & 5,96 & 25,60 & 4,10 & 5,51 & 52 & 019 & 18,50 & 4,90 & 6,01 & 19,20 & 4,90 & 6,06 \\
\hline 23 & $02 / 04 / 2019$ & 17,20 & 4,30 & 5,19 & 25,00 & 6,30 & 8,40 & 53 & $29 / 06 / 2019$ & 17,60 & 4,32 & 5,24 & 21,80 & 5,70 & 7,29 \\
\hline 24 & $05 / 04 / 2019$ & 17,80 & 4,70 & 5,72 & 25,50 & 3,90 & 5,23 & 54 & $03 / 07 / 2019$ & 13,30 & 5,40 & 6,23 & 24,00 & 5,10 & 6,71 \\
\hline 25 & $07 / 04 / 2019$ & 18,10 & 4,90 & 5,98 & 27,30 & 4,30 & 5,91 & 55 & $7 / 2019$ & 18,80 & 4,90 & 6,03 & 25,60 & 4,80 & 6,45 \\
\hline 26 & 09/04/2019 & 13,62 & 4,56 & 5,28 & 22,70 & 6,20 & 8,02 & 56 & 08/07/2019 & 15,10 & 4,40 & 5,18 & 24,90 & 6,50 & 8,66 \\
\hline 27 & $12 / 04 / 2019$ & 14,90 & 5,50 & 6,46 & 25,80 & 5,20 & 7,01 & 57 & $10 / 07 / 2019$ & 17,00 & 4,60 & 5,54 & 22,00 & 4,30 & 5,51 \\
\hline 28 & $13 / 04 / 2019$ & 15,08 & 5,44 & 6,41 & 25,10 & 4,80 & 6,41 & 58 & $12 / 07 / 2019$ & 13,37 & 6,05 & 6,98 & 23,60 & 6,30 & 8,25 \\
\hline 29 & $15 / 04 / 2019$ & 18,40 & 4,90 & 6,00 & 26,10 & 4,50 & 6,09 & 59 & & 13,70 & 7,00 & 8,11 & 19,50 & 6,50 & 8,07 \\
\hline 30 & $17 / 04 / 2019$ & 12,90 & 5,00 & 5,74 & 20,70 & 4,90 & 6,18 & 60 & $21 / 07 / 2019$ & 19,35 & 5,40 & 6,70 & 16,60 & 6,70 & 8,03 \\
\hline
\end{tabular}

Selanjutnya pada perhitungan persentase rasio $\Delta$ terhadap $\overline{a s h}_{d b}$ ditunjukkan oleh Tabel 3 dan dapat dilihat bahwa rasio sebagian di bawah $10 \%$ dan sebagian yang lain di atas $10 \%$ hingga $47 \%$ lebih. 
Tabel 3. Hasil Perhitungan Rasio

\begin{tabular}{|c|c|c|c|c|c|c|c|c|c|c|c|}
\hline \multirow{2}{*}{ No. } & \multicolumn{2}{|c|}{ Ash $(\mathrm{db}), \%$} & \multirow{2}{*}{$\overline{a s h}_{d b}$} & \multirow{2}{*}{$\begin{array}{l}\Delta, \\
\%\end{array}$} & \multirow{2}{*}{ Rasio } & \multirow{2}{*}{ No. } & \multicolumn{2}{|c|}{ Ash (db), \% } & \multirow{2}{*}{$\begin{array}{c}\overline{a s h}_{d b} \\
\%\end{array}$} & \multirow{2}{*}{$\begin{array}{l}\Delta, \\
\%\end{array}$} & \multirow{2}{*}{ Rasio } \\
\hline & Loading & Unloading & & & & & Loading & Unloading & & & \\
\hline 1 & 6,32 & 6,31 & 6,31 & 0,02 & $\begin{array}{|ll|}\vee & 0,27 \\
\end{array}$ & 31 & 5,56 & 6,25 & 5,90 & 0,69 & \$ 11,76 \\
\hline 2 & 5,90 & 5,51 & 5,70 & 0,39 & $\begin{array}{|ll|} & 6,79 \\
\end{array}$ & 32 & 6,94 & 7,07 & 7,00 & 0,13 & $\checkmark 1,81$ \\
\hline 3 & 5,95 & 6,62 & 6,29 & 0,67 & > 10,70 & 33 & 5,63 & 6,18 & 5,91 & 0,55 & $\checkmark 9,35$ \\
\hline 4 & 5,95 & 6,42 & 6,19 & 0,46 & $\begin{array}{|ll|} & 7,49 \\
\end{array}$ & 34 & 5,43 & 5,95 & 5,69 & 0,52 & $\checkmark 9,11$ \\
\hline 5 & 6,08 & 7,61 & 6,85 & 1,53 & - 22,27 & 35 & 6,30 & 7,29 & 6,79 & 0,99 & < 14,63 \\
\hline 6 & 8,72 & 7,89 & 8,30 & 0,83 & > 10,03 & 36 & 6,90 & 8,89 & 7,89 & 1,99 & $\times 25,24$ \\
\hline 7 & 8,12 & 11,98 & 10,05 & 3,86 & 238,39 & 37 & 5,45 & 5,87 & 5,66 & 0,42 & $\begin{array}{ll}, 40 \\
\end{array}$ \\
\hline 8 & 6,32 & 6,91 & 6,61 & 0,59 & $\begin{array}{|ll|} & 8,95 \\
\end{array}$ & 38 & 5,50 & 5,84 & 5,67 & 0,34 & $\checkmark 5,93$ \\
\hline 9 & 7,57 & 10,65 & 9,11 & 3,09 & \& 33,87 & 39 & 5,31 & 7,13 & 6,22 & 1,83 & $\times 29,35$ \\
\hline 10 & 7,35 & 9,79 & 8,57 & 2,44 & 228,42 & 40 & 7,22 & 9,04 & 8,13 & 1,82 & $\times 22,45$ \\
\hline 11 & 6,11 & 7,13 & 6,62 & 1,02 & - 15,37 & 41 & 7,15 & 6,88 & 7,02 & 0,27 & $\begin{array}{l}, 82 \\
\end{array}$ \\
\hline 12 & 6,66 & 6,62 & 6,64 & 0,04 & $\begin{array}{|ll|} & 0,60 \\
\end{array}$ & 42 & 5,89 & 5,93 & 5,91 & 0,04 & $\checkmark \quad 0,68$ \\
\hline 13 & 6,98 & 7,34 & 7,16 & 0,36 & $\begin{array}{|ll|} & 4,99 \\
\end{array}$ & 43 & 6,21 & 8,57 & 7,39 & 2,36 & 231,91 \\
\hline 14 & 6,10 & 6,23 & 6,17 & 0,13 & $\begin{array}{|ll|} & 2,17 \\
\end{array}$ & 44 & 6,35 & 7,21 & 6,78 & 0,86 & - 12,65 \\
\hline 15 & 8,45 & 6,18 & 7,31 & 2,27 & « 31,07 & 45 & 6,00 & 5,94 & 5,97 & 0,06 & 1,02 \\
\hline 16 & 6,10 & 8,78 & 7,44 & 2,68 & 36,01 & 46 & 6,14 & 5,73 & 5,94 & 0,41 & $\checkmark 6,89$ \\
\hline 17 & 5,86 & 6,13 & 6,00 & 0,27 & $\begin{array}{|ll|}\vee & 4,54 \\
\end{array}$ & 47 & 7,42 & 8,05 & 7,73 & 0,63 & $\begin{array}{ll}4 & 8,17 \\
\end{array}$ \\
\hline 18 & 6,10 & 7,16 & 6,63 & 1,06 & $\approx 16,01$ & 48 & 5,31 & 5,71 & 5,51 & 0,39 & 7,13 \\
\hline 19 & 6,67 & 8,01 & 7,34 & 1,34 & $\approx 18,24$ & 49 & 6,80 & 6,06 & 6,43 & 0,74 & 211,47 \\
\hline 20 & 5,41 & 5,76 & 5,58 & 0,35 & $\begin{array}{|lr|} & 6,28 \\
\end{array}$ & 50 & 5,51 & 5,72 & 5,62 & 0,20 & 3,62 \\
\hline 21 & 7,55 & 9,07 & 8,31 & 1,52 & $\approx 18,26$ & 51 & 6,23 & 5,73 & 5,98 & 0,50 & $\checkmark 8,33$ \\
\hline 22 & 5,96 & 5,51 & 5,74 & 0,45 & $\begin{array}{|ll|} & 7,85 \\
\end{array}$ & 52 & 6,01 & 6,06 & 6,04 & 0,05 & 0,86 \\
\hline 23 & 5,19 & 8,40 & 6,80 & 3,21 & त 47,18 & 53 & 5,24 & 7,29 & 6,27 & 2,05 & 232,66 \\
\hline 24 & 5,72 & 5,23 & 5,48 & 0,48 & $\begin{array}{|ll|} & 8,82 \\
\end{array}$ & 54 & 6,23 & 6,71 & 6,47 & 0,48 & 7,45 \\
\hline 25 & 5,98 & 5,91 & 5,95 & 0,07 & $\begin{array}{|ll|} & 1,15 \\
\end{array}$ & 55 & 6,03 & 6,45 & 6,24 & 0,42 & 6,68 \\
\hline 26 & 5,28 & 8,02 & 6,65 & 2,74 & 4 41,23 & 56 & 5,18 & 8,66 & 6,92 & 3,47 & > 50,19 \\
\hline 27 & 6,46 & 7,01 & 6,74 & 0,55 & $\begin{array}{|lr|} & 8,09 \\
\end{array}$ & 57 & 5,54 & 5,51 & 5,53 & 0,03 & $\checkmark 0,53$ \\
\hline 28 & 6,41 & 6,41 & 6,41 & 0,00 & $\begin{array}{|ll|} & 0,04 \\
\end{array}$ & 58 & 6,98 & 8,25 & 7,61 & 1,26 & $\approx 16,58$ \\
\hline 29 & 6,00 & 6,09 & 6,05 & 0,08 & $\begin{array}{|ll|}\vee & 1,40 \\
\end{array}$ & 59 & 8,11 & 8,07 & 8,09 & 0,04 & $\checkmark \quad 0,45$ \\
\hline 30 & 5,74 & 6,18 & 5,96 & 0,44 & \begin{tabular}{ll|} 
& 7,36 \\
\end{tabular} & 60 & 6,70 & 8,03 & 7,36 & 1,34 & 218,17 \\
\hline
\end{tabular}

Hasil pengolahan data secara statistik adalah sebagai berikut: $\bar{X}=13,503 \% ; S_{X}=12,734 \%$; interval kepercayaan $=3,290 \%$; dan rentang rasio $=13,503 \% \pm 3,290 \%$ atau dengan kata lain, rentang nilai rasio berada di antara $10,213 \%$ dan $16,793 \%$.

Kedua pengambilan sampel yang dilakukan di loading port dan unloading port pada suatu populasi batubara yang sama, menghasilkan rasio selisih terhadap rata-rata dry ash yang melebihi 10\%. Dengan kata lain, hasil analisa dry ash berdasarkan COA di kedua port memiliki selisih yang fluktuatif dan acak secara rasio. Kedua hasil analisa tidak dapat dijaga pada rasio maksimal $10 \%$ secara teratur dengan tingkat keyakinan 95\%. Hal ini membuktikan bahwa kedua pengambilan sampel metode non-probablity sampling tidak dapat dibandingkan sebagai acuan pengajuan umpire test. Sehingga jika terjadi perbedaan yang besar antara kedua analisa tersebut, maka kedua belah pihak harus sepakat dan maklum bahwa perbedaan tersebut sangat mungkin terjadi dan seharusnya tidak diperlukan upaya yang tidak tepat untuk memvalidasi perbedaan tersebut seperti joint sampling di unloading port. Yang diperlukan seharusnya adalah upaya memperbaiki (upgrade) kondisi pengambilan sampel menjadi kondisi B pada kedua port. 


\section{KILAT}

Vol. 9, No. 1, April 2020, P-ISSN 2089-1245, E-ISSN 2655-4925

DOI: https://doi.org/10.33322/kilat.v9i1.722

Ash (dry basis) selalu dijadikan sebagai parameter untuk keperluan biast test pada mechanical sampling kondisi B dan kalibrasi rotary divider pada proses preparasi. Parameter tersebut diyakini memiliki nilai yang stabil (presisi terjaga) jika proses sampling, preparasi, dan pengujian dilakukan memenuhi standar yang telah ditetapkan. Jika variabilitas parameter ash (dry basis) semakin besar, maka parameter lainnya tentu akan ikut terpengaruh sehingga validitas hasil analisa akan dipertanyakan.

\section{KESIMPULAN DAN SARAN}

Hasil penelitian ini telah membuktikan bahwa tidak tepat untuk melakukan perbandingan COA hasil non-probablity sampling di kedua pelabuhan. Hal ini dibuktikan dengan analisa statistik bahwa rentang rasio dengan tingkat kepercayaan 95\% didapatkan pada nilai di atas $10 \%$.

Terkait dengan hal tersebut di atas, penulis menyampaikan saran supaya klausul kontrak tentang umpire test dibuat lebih teknis dan rinci sehingga transaksi jual-beli batubara dapat memegang objektivitas yang benar sesuai standar. Selain itu, kondisi pengambilan sampel di loading port dan unloading port supaya dinaikkan menjadi kondisi B yang tidak bias (dibuktikan dengan bias test oleh kondisi A).

\section{UCAPAN TERIMA KASIH}

Penulis mengucapkan terima kasih kepada PT PLN (Persero) UIKL Kalimantan UPDK Balikpapan dan STT PLN yang telah memberi dukungan yang membantu pelaksanaan penelitian hingga terwujud.

\section{DAFTAR ISI}

[1] PT PLN (Persero), "Consolidated Financial Statements for The Years Ended December 31, 2018 and 2017," PT PLN (Persero), Jakarta, 2019.

[2] U. EPA, "Suppliers of Coal Technical Support Document (TSD)," 28 January 2008. [Online]. Available: https://www.regulations.gov/document?D=EPA-HQ-OAR-2008-0508-0037.

[3] S. W. Mwangi, "Probability and Non Probability Sampling," Asian Research Journal of Business Management, p. 115, 2017.

[4] ASTM International, D2234/D2234M - 16 Standard Practice for Collection of a Gross Sample of Coal, USA: ASTM International, 2016.

[5] ASTM Intenational, D7430 - 17 Standard Practice for Mechanical Sampling of Coal, USA: ASTM International, 2017.

[6] ASTM International, D6883 - 04 Standard Practice for Manual Sampling of Statiionary Coal from Railroad Cars, Barges, Trucks, or Stockpiles, USA: ASTM International, 2004.

[7] ASTM International, ASTM D2013/D2013M -12 Standard Practice for Preparing Coal Samples for Analysis, USA: ASTM International, 2012.

[8] ASTM International, D3173/D3173M - 17 Standard Test Method for Moisture in the Analysis Sample of Coal and Coke, USA: ASTM International, 2017.

[9] ASTM International, D3174 - 12 Standard Test Method for Ash in the Analysis Sample of Coal and Coke from Coal, USA: ASTM International, 2012.

[10] ASTM International, D3180 - 15 Standard Practice for Calculating Coal and Coke Analyses from As-Determined to Different Bases, USA: ASTM International, 2015. 